\title{
Early verb development in one German-speaking child*
}

\author{
Dagmar Bittner
}

Berlin

dabitt@zas.gwz-berlin.de

\section{Introduction}

This paper deals with the emergence of verb morphology in one German child up to the time mini-paradigms occur in the data. I will focus on the role of protomorphology as a transitional stage between rote learning and the productive use of morphological distinctions.

\section{Verb morphology in Standard German}

German is a language with a comparatively rich verb morphology. One central feature is subject-verb-agreement. Since there are some syncretisms in agreement symbolization, pro drop constructions are restricted to special contexts. The categories person, number, tense, mood, and voice are realised by verb inflection. The system of these categories encloses 144 paradigmatic positions for each verb. Paradigmatic forms can be fusional (sag-te 'say-' 3.sg.prät.ind.act.) or analytic (wird gesagt werden 'will be said' 3.sg.fut.ind.pass.).

In the present study I will concentrate on the facts of German verb inflection which are relevant in the acquisition processes in pre- and protomorphology of the child Anna.

In the investigated period of time Anna acquires the following types of verbs:

a) lexical verbs in present tense (cf. table 1 and (1))

b) sein-copula in present and past tense (cf. table 2 and 3 )

c) modal verbs in present tense (cf. table 4)

d) past participles and analytical perfect (cf. (2) and (3))

Table 1: person-/number-inflection of lexical verbs (example: machen 'to do')

\begin{tabular}{l|ll} 
& singular & plural \\
\hline 1. person & mach-e & mach-en \\
2. person & mach-st & mach-t \\
3. person & mach-t & mach-en
\end{tabular}

Strong verbs can have a stem vowel alternation in the singular paradigm, cf.

$\begin{array}{llrrr}\text { (1) inf:: fahren } & \text { 'to drive' } & \text { 1sg: fahre } & \text { 2sg: fährst } & \text { 3sg: fährt } \\ \text { sehen } & \text { 'to see' } & \text { sehe } & \text { siehst } & \text { sieht, } \\ \text { geben } & \text { 'to give' } & \text { gebe } & \text { gibst } & \text { gibt }\end{array}$

Table 2: person-/number-forms of seincopula in present tense

\begin{tabular}{l|ll} 
& singular & plural \\
\hline 1. person & bin & sind \\
2. person & bist & seid
\end{tabular}

Table 3: person-/number-forms of seincopula in past tense

\begin{tabular}{l|ll} 
& singular & plural \\
\hline 1. person & war & waren \\
2. person & warst & wart
\end{tabular}

* For helpful comments on a first version of this paper I would like to thank Wolfgang U. Dressler, Natalia Gagarina, Insa Gülzow, Marianne Kilani-Schoch and Sabine Klampfer as well as all participants of the workshop 'Early verbs. On the way to mini-paradigms' in late September 2000 at the ZAS in Berlin. 
3. person | ist sind $\quad$ 3. person |war waren

Table 4: person-/number-forms of modal verbs (example: können 'can')

\begin{tabular}{l|ll} 
& singular & plural \\
\hline 1. person & kann & könn-en \\
2. person & kann-st & könn-t \\
3. person & kann & könn-en
\end{tabular}

Past participle in adult German is formed by the Präfix ge- + the verb stem + suffix $-t$. Again, strong verbs can show stem vowel alternation and/or can take suffix - en instead of $-t$, cf:

(2) weak verbs

$\begin{array}{lllllll}\text { machen 'to do' } & \text { - gemacht 'done' } & \text { bringen 'to bring' } & \text {-gebracht 'brought' } \\ \text { kaufen } & \text { 'to buy' } & \text { - gekauft 'bought' } & \text { gehen } & \text { 'to go' } & \text { - gegangen 'gone' }\end{array}$

Analytical perfect (the target form of perfect tense) is formed with the present tense form of the verb sein 'be' or haben 'have' + past participle.

$\begin{array}{llll}\text { er ist gekommen } & \text { 'he has come' } & \text { er hat geglaubt } & \text { 'he has thought' } \\ \text { sie sind gerannt } & \text { 'they was running' } & \text { sie haben geschlafen } & \text { 'they have slept }\end{array}$

With respect to productivity of inflectional classes we can restrict the description to the fact that the inflectional pattern of weak verbs is the most and at least the only productive one. Strong verbs can be divided in a range of sub- or microclasses according to their patterns of stem vowel alternation and the pattern of strong and weak forms in the set of category symbolizations of the verb, cf. A. Bittner (1995). ${ }^{1}$ However, because Anna is not producing forms of strong verbs in other than present tense or perfect forms it is not necessary to go into more detail here. The only feature of strong verbs which is relevant in the data is the stem vowel alternation in pres.sg. This feature occurs in different classes of strong verbs. ${ }^{2}$

\section{Data description}

For the present study I analysed the first ten recordings of longitudinal data of the girl Anna covering an the age range of $1 ; 8,10-2 ; 1,13$ covering 10 recordings (table 1 ). ${ }^{3}$ Recordings mainly took place at Anna's home where the experimenter was playing with Anna, sometimes together with her parents. Occasionally kitchen work, dinner and other home situations are included.

Table 5: data description

\begin{tabular}{|c|c|c|c|}
\hline $\begin{array}{c}\text { number of } \\
\text { recording }\end{array}$ & age & $\begin{array}{c}\text { time of recording } \\
\text { (in minutes) }\end{array}$ & $\begin{array}{c}\text { number of analyzed } \\
\text { utterances }\end{array}$ \\
\hline 1 & $1 ; 8,10$ & 65 & 293 \\
\hline 2 & $1 ; 8,29$ & 57 & 218 \\
\hline 3 & $1 ; 9,14$ & 75 & 237 \\
\hline 4 & $1 ; 10,0$ & 61 & 266 \\
\hline 5 & $1 ; 11,6$ & 70 & 313 \\
\hline 6 & $1 ; 11,20$ & 75 & 284 \\
\hline 7 & $1 ; 11,30$ & 46 & 248 \\
\hline 8 & $2 ; 0,5$ & 51 & 292 \\
\hline
\end{tabular}

1 As A. Bittner (1995) showed, diachronic facts give evidence for systematic and strongly directed step by step change of strong to weak forms.

2 Compare the description of inflectional classes of German verbs in Klampfer (this volume).

3 The data were audio- and partly videotaped by myself. The transcription and morphological coding with the CLAN program of CHILDES (MacWhinney 2000) was done by Franziska Bewer and Jocrg von Thun.

4 All utterances not containing at least one meaningful lexical unit resembling a German word in form and meaning as well as pure yes/no utterances have been excluded from the analyses. 


\begin{tabular}{|c|c|c|c|}
\hline 9 & $2 ; 0,29$ & 94 & 503 \\
\hline 10 & $2,0.13$ & 89 & 348 \\
\hline
\end{tabular}

Anna is the only child of a Berlin middle class family. Her parents speak Standard German with only a few phonological elements of the Berlin dialect. Since the age of 1;0 Anna regularily visited the kindergarten. Anna can be seen as an early talker and a rather segmental child. Formulaics, frozen forms and imitations are less documented in the data.

With respect to the emergence of morphology we can assume the following developmental periods in Anna's data:

$$
\begin{array}{ll}
\text { Premorphology: } & 1 ; 8,10-1 ; 10,0 \\
\text { Protomorphology: } & 1 ; 11,6-2 ; 0,5
\end{array}
$$

The transition from pre- to protomorphology between $1 ; 10,0$ and $1 ; 11,6$ is marked by the occurence of the first three member paradigms of verbs as well as by an increasing use of the bare infinitive as (unspecified) default form of the verb (cf. 4.3.2 and Table 16 for 1;11,6). Especially the latter shows that the child is overcoming the phase of using only rote learned forms. We also find development in other domains, like an increase in plural forms of nouns, the productive use of the deictic pronoun das, the emergence of personal pronouns and a considerable development in syntactic complexity (occurence of 2 argument utterances) can be observed.

\section{Predecessors of verbs in predicative function}

Anna already uses a considerable number of verbs at the beginning of the recordings - 31 lexemes are documented in the two recordings at 1;8. Extragrammatical predecessors of verbs are not (longer?) documented. What could be found in the data is a remarkable amount of verbal prefixes and adverbs replacing lexical verbs (34 instances in the first recording), cf. $a b$ 'from/off', putt 'broken/smash', auf 'open/up', weg 'away/off'.

(4) EXP: das ist vom heft; von papas heft. ANN: ab.

Exp: geht nicht ab.

ANN: putt.

EXP: das geht nicht ab.

ANN: putt.

\author{
'this is (a part) of a notebook, of papa's notebook' \\ '(I want to get it) off' \\ '(it) doesn't come off' \\ '(I want it to) break/(it shall be) broken' \\ 'it doesn't come off' \\ '(I want it to) break/(it shall be) broken ${ }^{5}$
}

Contrary to the increasing number of verbs (cf. (5)) the amount of pure verbal prefixes decreases in the following recordings ( 21 and 24 in the next two recordings). ${ }^{6}$

In the first three recordings the amount of one-word-utterances is still around two-thirds of all analyzed utterances. As long as the child has not acquired the production of more than one syntactical position per utterance s/he is forced to decide which one of the relevant components of the information should be expressed. In one-word-utterances only the focus of the information the child wants to express is given. In many cases an alternative choice of a verb or another lexical element will be possible. I prefer to consider one-word-utterances without verbs as an omission or drop (cf. topic drop) of the relevant verbal unit rather than as a replacement of the verb by other elements.

5 Anna has found an old notebook of her father and tries to take off the metal fixture for the sheets.

6 To verbal prefixes in German child language compare a.o. Vollmann et al (1997:64f), Bennis et al (1995). 


\section{Emergence of verbs}

\subsection{The data}

Table 6 shows the development of verb usage by Anna from a quantitative point of view. The transition from pre- to protomorphology between $1 ; 10,0$ and $1 ; 11,6$ is accompanied by a clear spurt in the amount of utterances with verbs. From 1;11,6 on more than $50 \%$ of the analyzed utterances contain a verb.

Table 6: development of verb usage

\begin{tabular}{|c|c|c|c|c|}
\hline \multirow[t]{2}{*}{ age } & \multirow{2}{*}{$\begin{array}{c}\text { number of analyzed } \\
\text { utterances }\end{array}$} & \multicolumn{2}{|c|}{ uttcrances with verbs } & \multirow[t]{2}{*}{ verb tokens ${ }^{7}$} \\
\hline & & numbe & $\%$ & \\
\hline $1 ; 8,10$ & 293 & 52 & 17,7 & 45 (+ 7 imit./froz. $)$ \\
\hline $1 ; 8,29$ & 218 & 76 & 34,8 & 47 (+30 imit./froz. $)$ \\
\hline $1 ; 9,14$ & 237 & 65 & 27,4 & $53(+12 \mathrm{imit} /$ froz. $)$ \\
\hline $1 ; 10,0$ & 266 & 86 & 32,3 & 67 (+19 imit./froz.) \\
\hline $1 ; 11,6$ & 313 & 165 & 52,7 & 144 (+ 27 imit./froz. $)$ \\
\hline $1 ; 11,20$ & 284 & 147 & 51,8 & 116 (+36 imit./froz.) \\
\hline $1 ; 11,30$ & 248 & 132 & 53,2 & 92 (+43 imit./froz.) \\
\hline $2 ; 0,5$ & 292 & 150 & 51,4 & $111(+41$ imit./froz. $)$ \\
\hline $2 ; 0,29$ & 523 & 293 & 56,0 & 277 (+ 48 imit./froz.) \\
\hline $2,0.13$ & 348 & 209 & 60,0 & 201 ( +25 imit./froz.. $)$ \\
\hline
\end{tabular}

Possibly a further developmental spurt has taken place between $2 ; 0,5$ and $2 ; 0,29$. I will discuss this later on.

The following analyses will concentrate on verb forms that could be regarded as spontaneous productions in the sense that they are not frozen or citation forms, and not imitations of verb forms of the preceeding utterance of the adult. ${ }^{8}$ Table 7 gives the remaining number of lemmas, types and tokens per utterance.

Table 7: verb lemmas/types/tokens

\begin{tabular}{|c|c|c|c|}
\hline age & lemmas & types & tokens \\
\hline $1 ; 8,10$ & 25 & 28 & 45 \\
\hline $1 ; 8,29$ & 22 & 23 & 47 \\
\hline $1 ; 9,14$ & 32 & 42 & 53 \\
\hline $1 ; 10,0$ & 28 & 36 & 67 \\
\hline $1 ; 11,6$ & 66 & 83 & 144 \\
\hline $1 ; 11,20$ & 52 & 68 & 116 \\
\hline $1 ; 11,30$ & 45 & 57 & 92 \\
\hline $2 ; 0,5$ & 40 & 54 & 111 \\
\hline $2 ; 0,29$ & 100 & 134 & 277 \\
\hline $2 ; 0,13$ & 67 & 97 & 201 \\
\hline
\end{tabular}

Again, one finds a spurt between $1 ; 10,0$ and 1;11,6, which is clearly not an artefact of the increasing number of analyzed utterances, cf. the equal numbers of analyzed utterances in $1 ; 8,10$ and $1 ; 11,20$ or in $1 ; 9,14$ and $1 ; 11,30$ despite of different numbers of lemmas, types and tokens, and of utterances with verbs in the respective recordings.

\subsection{The premorphological phase}

\subsubsection{Form analysis}

Inflected verbs are the first inflected forms documented in Anna's data beside a small amount of nominal plural forms ( 5 lemmas/ 10 tokens in the $1^{\text {st }}$ recording). It is a well known fact that

7 The different verbs of a periphrastic construction are counted as seperate tokens, i.e. two tokens per periphrastic construction.

8 For definitions compare the Introduction to this volume by. 
acquisition of verbs in German is characterized by an extended use of bare infinitives, i.e. of -en forms. ${ }^{9}$ This holds to be true in the data of Anna, cf. table 8. However, she also uses a considerable amount of $-t$ forms at the beginning of the recordings. ${ }^{10}$ But the verb machen to do' is the only verb that shows $-t$ forms beside -en forms since the $1^{\text {st }}$ recording.

Table 8: formal analysis of verb forms (lemmas/tokens)

\begin{tabular}{|l|l|l|l|l|l|}
\hline age & -en & -t & $-\varnothing$ & -e & past participle ${ }^{\mathrm{I1}}$ \\
\hline $1 ; 8,10$ & $13 / 23$ & $9 / 15$ & $6 / 6$ & & $1 / 1$ \\
\hline $1 ; 8,29$ & $10 / 30$ & $11 / 13$ & $/$ & & $2 / 2$ \\
\hline $1 ; 9,14$ & $20 / 25$ & $16 / 23$ & $2 / 2$ & $2 / 2$ & $1 / 1$ \\
\hline $1 ; 10,0$ & $15 / 33$ & $9 / 15$ & $9 / 16$ & $1 / 1$ & $2 / 2$ \\
\hline
\end{tabular}

Most verbs are documented with only one form in this phase and a lot of them are documented merely once at all. Only 10 of the 72 verb lemmas of this phase occur in three of the four recordings.

Beside $-e n$ and $-t$ forms pure stem forms are documented. These are rather ommissions of the word ending than inflected forms. With the only exception of mal (1sg.pres.ind.) 'to draw' there is no clear evidence that these forms are used as imperatives or 1sg.pres. forms, which are the target categories of these forms.

In the observed phase 6 clear past participle forms are documented: puttemacht, einepullert, raufemach and iebn 'written' (= geschrieben; infin. schreiben), puttgangen 'broken down' (= kaputtgegangen; infin. gehen), mitbracht 'brought along' (= mitgebracht; infin. bringen).

\subsubsection{Form-context analysis}

In the premorphological phase Anna uses only present tense forms of verbs and the 6 past participle forms already mentioned.

Because of uncertainty or lack of the subject element it is mostly hard to decide to which agreement category a verb form belongs. Thus in 1;8,10 only 9 out of 45 verb tokens and in $1 ; 10,0$ only 9 out of 67 are accompanied by a subject element.

Tables 9-12 represent the analyses of category contexts for each inflectional type in the premorphological period. The title of column 2 'unclear category' means there is a present form for which the agreement category can not be specified. All forms occuring in a context of order or request are counted as imperatives (column 7). ${ }^{12}$ The past participle forms are the only forms unambiguously assigning perfectivity or resultativity (column 8 and 9). ${ }^{13}$ There are a lot of further contexts where perfectivity is probable given in the context situation. But due to the uncertainty of decision all of these instances are counted in the present tense columns. The dark columns assign the target categories of the respective inflectional form. ${ }^{14}$

9 The occurance of bare infinitives in early verb acquisition in various languages is discussed under the term 'optional infinitive stage', cf. Wexler (1994). For German compare Clahsen et al (1993), Weissenborn (1994).

10 Recall that $-t$ is the target suffix of the 3.sg./2.pl.pres.ind.act. and as well of the past participle, cf. chapter 2 . It is the most frequent suffix after $-e n$.

11 Here are counted only clear past participle forms, i.e. forms having a stem change and/or the prefixe -ge- or its reduced form $-e$ -

12 Again, due to the lack of utterance context it is often hard to decide if the child uttered an order/a request or not. In column 9 only the (relatively) clear instances are counted. In case of uncertainty the form is counted as present tense form.

13 Cf. the discussion of perfectivity and its assignment in the data in ch. 4.3.2. and 6.2., 6.3. Note that column 8 +9 only correspond with column 6 of table 8 .

14 Deep dark $=$ unmarked target form, light dark $=$ marked target form. 
Table 9: -en forms in synthetic verb constituents (lemmas/tokens)

\begin{tabular}{|c|c|c|c|c|c|c|c|c|}
\hline \multirow[t]{2}{*}{ age } & \multicolumn{5}{|c|}{ present } & \multirow[t]{2}{*}{$\begin{array}{c}\text { imper. } \\
\text { (=order) }\end{array}$} & \multicolumn{2}{|c|}{$\begin{array}{c}\text { perfect } \\
\text { (past participle) }\end{array}$} \\
\hline & ambig & $1 \mathrm{sg}$ & $2 s g$ & $3 \mathrm{sg}$ & 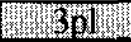 & & $1 \mathrm{sg}$ & $3 \mathrm{sg}$ \\
\hline $1 ; 8,10$ & $10 / 13$ & & & $3 / 3$ & & $2 / 7$ & & $1 / 1$ \\
\hline $1 ; 8,29$ & $9 / 20$ & $1 / 1$ & & $2 / 6$ & 11111 & $1 / 2$ & & $1 / 1$ \\
\hline $1 ; 9,14$ & $14 / 17$ & $2 / 2$ & $1 / 1$ & $2 / 2$ & 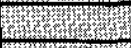 & $3 / 3$ & & \\
\hline $1 ; 10,0$ & $11 / 18$ & $3 / 6$ & $1 / 1$ & $1 / 1$ & $2 / 30$ & $3 / 4$ & & \\
\hline
\end{tabular}

Table 10: -t forms in synthetic verb constituents (lemmas/tokens)

\begin{tabular}{|c|c|c|c|c|c|c|c|c|}
\hline \multirow[t]{2}{*}{ age } & \multicolumn{5}{|c|}{ present } & \multirow[t]{2}{*}{$\begin{array}{c}\text { imper. } \\
\text { (=order) }\end{array}$} & \multicolumn{2}{|c|}{$\begin{array}{c}\text { perfect } \\
\text { (past participle) }\end{array}$} \\
\hline & ambig & $1 \mathrm{sg}$ & $2 s g$ & 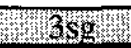 & $3 \mathrm{pl}$ & & 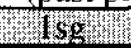 & Whes \\
\hline $1 ; 8,10$ & $5 / 5$ & & & WTWO & & & 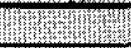 & \\
\hline $1 ; 8,29$ & $4 / 4$ & $1 / 1$ & & $6 / 8$ & & & 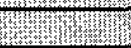 & $(1 / 1$ \\
\hline $1 ; 9,14$ & $3 / 5$ & $4 / 4$ & & mIOTU4 & & & 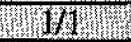 & WTHW \\
\hline $1 ; 10,0$ & $3 / 3$ & $2 / 3$ & & my & & & $W_{W}$ & $\mathrm{~F}_{\text {m }}$ \\
\hline
\end{tabular}

Table 11: $\varnothing$ forms in synthetic verb constituents (lemmas/tokens)

\begin{tabular}{|c|c|c|c|c|c|c|c|c|}
\hline \multirow[t]{2}{*}{ age } & \multicolumn{5}{|c|}{ present } & \multirow{2}{*}{ 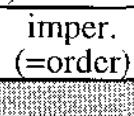 } & \multicolumn{2}{|c|}{$\begin{array}{c}\text { perfect } \\
\text { (past participle) }\end{array}$} \\
\hline & ambig & 189 & $2 \mathrm{sg}$ & $3 \mathrm{sg}$ & $3 \mathrm{pl}$ & & $1 \mathrm{sg}$ & $3 \mathrm{sg}$ \\
\hline $1 ; 8,10$ & $2 / 2$ & $2 / 2$ & & $1 / 1$ & & Whew & & \\
\hline $1 ; 8,29$ & & 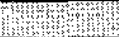 & & & & 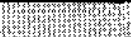 & & \\
\hline $1 ; 9,14$ & & 22 & & & & 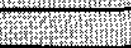 & & \\
\hline $1 ; 10,0$ & $4 / 6$ & 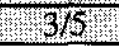 & & $2 / 2$ & $1 / 1$ & WWII & $1 / 1$ & \\
\hline
\end{tabular}

Table 12: -e forms in synthetic verb constituents (lemmas/tokens)

\begin{tabular}{|c|c|c|c|c|c|c|c|c|}
\hline \multirow[t]{2}{*}{ age } & \multicolumn{5}{|c|}{ present } & $\begin{array}{l}\text { imper. } \\
(=\text { order })\end{array}$ & \multicolumn{2}{|c|}{$\begin{array}{c}\text { perfect } \\
\text { (past participle) }\end{array}$} \\
\hline & ambig & IIs & $2 \mathrm{sg}$ & $3 \mathrm{sg}$ & $3 \mathrm{pl}$ & 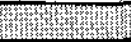 & $1 \mathrm{sg}$ & $3 \mathrm{sg}$ \\
\hline $1 ; 9,14$ & $2 / 2$ & 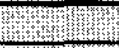 & & & & 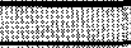 & & \\
\hline $1 ; 10,0$ & & 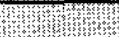 & & & & 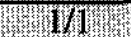 & & \\
\hline
\end{tabular}

We can conclude that - en forms are spread over the entire field of the occuring category contexts whereas $-t$ forms are more or less restricted to 3.sg.pres. Especially with $-t$ forms often a perspective or a resultative meaning seems to be intended. Possibly they are used instead of target past participle forms. In the order of the recordings there are at least $2-5$ $10-6$ instances of this case.

With respect to pure stem forms $(-\ell)$ and to $-e$ forms it becomes obvious over time that Anna prefers the stem form to express $1 . \mathrm{sg}$ and imperative. The occurence of $-\varnothing$ forms in other contexts is mainly due to articulatory reductions at the word ending. Thus we find papa guck (=guck-t?) 'daddy looks' (no imperative!), das hier ha (=hab-en?) 'want this here', aufräum (=aufräum-en?) 'tidy up'.

Only one analytical construction is documented in premorphology: hat kauft 'has bought' $(1 ; 8,29)$. Instances of modal verbs are not documented (beside one unclear occurence of darf (1/3sg form of diurfen 'be allowed to') in 1;9,14).

\subsubsection{Emergence of categories in premorphology}

According to Dressler/Karpf (1995) premorphology is considered to be the phase in acquisition where the child has not started to use morphological operations of the target language but shows distinction of actions/situations by the use of specific extragrammatical forms or of rote learned forms. ${ }^{15}$ Precursors of morphological operations are based on universal principles of grammatical symbolization like iconicity, transparency, uniformity (cf.

15 For comparable but in parts different scenarios on this carly phase, compare the assumptions of Slobin (1985:1164ff) on carly mapping and grammaticizable notions, and of Tomasello $(1992,2000)$ on the verb island hypothesis and on imitative learning. 
the introduction). As we have seen in the previous chapters Anna distinguishes between -en and $-t$ forms of verbs in premorphology. In adult language the -en form only occurs as infinitive in periphrastic constructions. Anna doesn't produce periphrastic constructions in the observed phase. Nevertheless, she (like other German children) uses this form in nearly all category contexts she employs. On the other hand $-t$ forms occur mainly in 3.sg.pres.ind. contexts. Whereas the $-e n$ form is not related to a special verb category the $-t$ form seems to be related to objects that are not speaker or hearer. Thus one could conclude that -en is a feature for beeing a verb and that $-t$ is a feature for beeing a verb in a special context. But all the forms documented in premorphology have to be assumed to be rote learned, i.e. they are not the output of a morphological operation. 57 of the 72 lemmas in premorphology are used with only one morphological form $(30 \mathrm{x}-e n, 18 \mathrm{x}-t, 4 \mathrm{x}$ past participle, $4 \mathrm{x}$ stem, $1 \mathrm{x}-e=>$ $79 \%$ ).

As long as the forms have to be categorized as rote learned we can't know if the child is aware of the grammatical content of these forms and of the respective grammatical categories. We can only register the emergence of forms in specific grammatical environments. With respect to the latter, only contexts resembling 3.sg.pres.ind. in adult language are specified in Anna's speech in premorphology. At the very end of this phase also contexts resembling 1.sg.pres.ind. correlate with the occurence of a special form, the stem form.

\subsubsection{Emergence of form contrasts in premorphology}

A total of 279 utterances containing a verb, 72 'selfproduced' verb lemmas and 212 'selfproduced' verb tokens are documented in the four recordings of the premorphological phase. Among these forms only 12 lemmas show different forms within the same recording and we can't preclude that all of these contrasts are a result of rote learning or unmotivated phonological variation. Table 13 gives the number of form contrasts per recording:

Table 13: number of lemmas with form contrasts

\begin{tabular}{|c|c|c|}
\hline age & 2 forms & 3 forms \\
\hline $1 ; 8,10$ & 1 & \\
\hline $1 ; 8,29$ & 1 & \\
\hline $1 ; 9,14$ & 7 & 1 \\
\hline $1 ; 10,0$ & 4 & 2 \\
\hline
\end{tabular}

The dominant contrast is that between an -en and a $-t$ form (involved in 10 cases). Only in one case no $-t$ form is involved in the form distinctions. Whereas the -en form occurs in many cases in one word (verb) utterances with unclear category context the - $t$ form mainly occurs in 1./3.sg.pres. context or in contexts where perfective meaning could be assumed, cf.

$\begin{array}{lll}1 ; 8,10 & \text { machen } & ? \\ 1 ; 8,29 & \text { bauen } & ? / \text { request } \\ 1 ; 9,14 & \text { gucken } & ? \\ & \text { machen } & ? \\ & \text { aufmachen } & ? \\ & \text { malen } & \text { request } \\ & \text { pullern } & 1 . \text { sg.pres. } \\ & \text { aufsetzen } & ?\end{array}$

$\begin{array}{lll}\begin{array}{l}\text { macht } \\ \text { baut }\end{array} & \text { 3.sg.pres. / past part.? } & \text { 'to do' } \\ \text { guckt } & ? & \text { 'to build' } \\ \text { macht } & ? & \text { 'to look' } \\ \text { aufmacht } & \text { 3.sg.pres. / past part.? } & \text { 'to do' } \\ \text { malt } & \text { past part.? } & \text { 'to open' } \\ \text { pullert } & \text { past part.? } & \text { 'to piddle' } \\ \text { aufsetzt } & \text { past part.? } & \text { 'to put on' } \\ \text { gebt } \text { vs. gibt } & \text { past part.? - 3.sg.pres. } & \text { 'to give' }\end{array}$

Phonological variation due to omission of the word ending or of the past participle prefix is very probable in the distinctions of kauft - kauf 'to buy', zumacht - zumach 'to close', einpullert - einepullert 'to piddle'.

Since we are interested in the development up to the emergence of mini-paradigms which are defined as distinction of at least three inflectional forms we will have a closer look at the 
cases with three forms of one lemma. In the whole period there are only three lemmas documented with three (or more) different forms in the same recording, cf.

$$
\begin{aligned}
& \text { (ka)puttmach }-(\text { ka)puttmacht }-(\text { ka)puttemacht - mache putt 'break down' } \\
& \text { 1.sg.pres. - 1.sg. (perf? past part.?) - 1.sg.perf. (past part.) - uncl.category }
\end{aligned}
$$

Three forms of this lemma occur in 1.sg. contexts only. The included functional distinction seems to be that between imperfectivity and perfectivity.

With the second verb the form-function-relations become more target like. However, there are instances of unclear category context with every form, $\mathrm{cf}$.

$\begin{array}{llll}1 ; 10,0 & \begin{array}{l}\text { malen } \\ \text { uncl. category } \\ \text { request } \\ \text { 1.sg.pres. }\end{array} & \begin{array}{l}\text { uncl. category } \\ \text { 3.sg.pres. }\end{array} & \begin{array}{l}\text { mal } \\ \text { uncl. category } \\ \text { 1.sg.pres. }\end{array}\end{array}$ 'to draw'

The last one shows the more or less typical picture for each of the three forms at the end of the premorphological phase. However, one hardly finds clear inflectional contrasts with one and the same lemma in the data. In the case of bauen 'to build' the form baut is documented only twice. One time with an unclear category context, one time in 3.sg.pres.ind. context. The form bau is documented only once in whole premorphology.

$$
\begin{gathered}
\text { bauen - baut - bau } \\
\text { unel. category - 3.sg.pres. - 1.sg.pres.? }
\end{gathered}
$$

'to build'

Taking into account that inflection is determined by the verb stem in German it is reasonable to look beyond the lemma. Integrating all verb forms of one verb stem we can add machen (uncl. cat.) and macht (3.sg.pres.ind.) to the forms in (6). There are 4 different forms of the verb stem mach- in 1;10,0 to. Further we could add the form contrast:

$$
\begin{gathered}
\text { pullern - pullert }(1 ; 9,14) \text { - puller - einepullert } \\
\text { 1sg.pres.ind. - 1sg.pres.ind. - 1sg.pres.ind. - past participle (1sg) }
\end{gathered}
$$

'to piddie'

But here again the category contexts are unclear or identical.

The analysis shows that Anna is handling all target forms of present indicative except the $-s t$ form in premorphology. However, their grammatical meaning still has to be discovered.

\subsection{The protomorphological phase}

\subsubsection{Form analysis}

At 1;11,6 we can observe a considerable spurt concerning the usage of verbs. 35 new lemmas are documented, cf. the occurence of new lemmas per recording:

(10) premorphological phase $25>+15>+21>+11$ protomorphological phase $+\mathbf{3 5}>+19>+22>+15(>+\mathbf{4 3}>+22)$

Among the new lemmas we find the first modal verbs. As well a greater number of periphrastic verb constructions occur for the first time. From now on more than $50 \%$ of Anna's utterances consistantly contain a verb (cf. table 6).

The form analyses (table 14) show that no remarkable enrichment of verb forms (types) has taken place. Only pure stem forms $(-\varnothing)$ occur more regularly than in premorphology. The $-e$ forms and the past participle forms are used as sporadically as before. At the very end of the protomorphological phase the first -st form is documented. We can take it as a hint that transition to the next phase has started. 
Table 14: formal analysis of verb forms in protomorphology and the transition phase to modularized morphology

\begin{tabular}{|c|c|c|c|c|c|c|c|}
\hline age & -en & $-\mathrm{t}$ & $-\varnothing$ & -e & past part & -st & -te \\
\hline $1 ; 11,6$ & $48 / 86$ & $19 / 33$ & $11 / 18$ & $1 / 1$ & $3 / 5$ & & \\
\hline $1 ; 11,20$ & $34 / 58$ & $14 / 29$ & $16 / 23$ & $3 / 3$ & & & \\
\hline $1 ; 11,30$ & $27 / 45$ & $18 / 37$ & $8 / 10$ & $1 / 1$ & & & \\
\hline $2 ; 0,5$ & $25 / 53$ & $16 / 38$ & $10 / 18$ & & & $1 / 1$ & \\
\hline $2 ; 0,29$ & $66 / 120$ & $27 / 65$ & $20 / 62$ & $2 / 2$ & $5 / 8$ & $4 / 7$ & $2 / 4$ \\
\hline $2 ; 1,13$ & $35 / 67$ & $23 / 50$ & $22 / 70$ & $6 / 8$ & $2 / 2$ & $6 / 6$ & \\
\hline
\end{tabular}

At $2 ; 0,29$ the acquisition of verb morphology reaches a new quality. It turns out by 7 target like forms of 2.sg.pres.ind. in - st, by 32 periphrastic verb constructions (which is more than the dobble of all periphrastic constructions before) and by the emergence of first past forms of lexical verbs in -te (woll-te 'wanted' (3 times), klopf-te 'knocked'). Except of the emergence of -te forms this new development is confirmed in $2 ; 1,13$. It can be assumed that Anna overcomes the protomorphological phase around 2,1 . The following analysis is concentrated on the development up to $2 ; 0,5$. The recordings of $2 ; 0,29$ and $2 ; 1,13$ will be analysed with respect to the emergence of inflectional categories and true mini-paradigms.

\subsubsection{Form-context-analysis}

The increasing number of verb lemmas (10) and tokens (table 6) in the protomorphological phase initially leads to a rapid increase of $-e n$ forms. These forms are still spread across the entire set of the present tense categories. Only -en forms of modal verbs occur without any exception in their target categories of 1./3.plural. As in premorphology $-t$ forms and stem forms $(-\varnothing)$ occur predominantly target like in 3.sg.pres.ind. and 1.sg.pres.ind. contexts. For most cases of $-t$ forms occuring in nontarget agreement contexts a perfective meaning can be assumed. Nontarget occurences of stem forms $(-\varnothing)$ often have a nasal, a palatal or a complex consonantal stem ending (komm, mitnehm, puttgang, anguck, reinsetz) which makes the (consonantal) inflectional endings difficult to articulate and to perceive.

The en form without any category specification is still the dominant form. However, an increasing number of plural contexts is documented and the target function as infinitive of periphrastic forms starts to develop, cf. (13). Inflectional categories typically assigned by other forms are 1./3.sg.pres.ind. The few clear past participle forms (table 14) can still be assumed to be rote learned. Also in $2 ; 0,29$ and $2 ; 1,13$ nearly no use of the past participle prefix $g e$ - could be found.

Tables 15-19 give the distribution of the forms over the target category contexts and demonstrate the extension of plural contexts and the occurence of modal verbs as the new development in this phase.

16 Notice that the table includes all tokens in all documented verb forms, in synthetic as well as in periphrastic ones. Thus the numbers in this table don't equal the numbers in tables 15-19. 
Table 15: -en forms in synthetic verb constituents (lemmas/tokens)

\begin{tabular}{|c|c|c|c|c|c|c|c|c|c|c|c|}
\hline \multirow[t]{2}{*}{ age } & \multicolumn{6}{|c|}{ present } & \multicolumn{2}{|c|}{ modals } & \multirow[t]{2}{*}{$\begin{array}{l}\text { Imper. } \\
\text { (order) }\end{array}$} & \multicolumn{2}{|c|}{$\begin{array}{c}\text { perfect } \\
\text { (past participle) }\end{array}$} \\
\hline & ambig & $1 \mathrm{sg}$ & $2 \mathrm{sg}$ & $3 \mathrm{sg}$ & 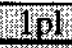 & (3) & $3 \mathrm{sg}$ & W10 & & $1 \mathrm{sg}$ & 3sg \\
\hline $1 ; 11,6$ & $33 / 44$ & $9 / 11$ & & $14 / 23$ & When & 鑃 & & TEx: & & & $1 / 1$ \\
\hline $1 ; 11,20$ & $26 / 36$ & $2 / 3$ & $2 / 3$ & $5 / 6$ & WWW" & Why & & WWW"WW & $5 / 6$ & & \\
\hline $1 ; 11,30$ & $15 / 21$ & $3 / 3$ & & $5 / 7$ & 313 & Wha & & WWhen & $4 / 6$ & & $1 / 1$ \\
\hline $2 ; 0,5$ & $14 / 27$ & $7 / 8$ & $1 / 1$ & $4 / 6$ & $2 / 2$ & When & & 14 & $3 / 3$ & & \\
\hline
\end{tabular}

Table 16: -t forms in synthetic verb constituents (lemmas/tokens)

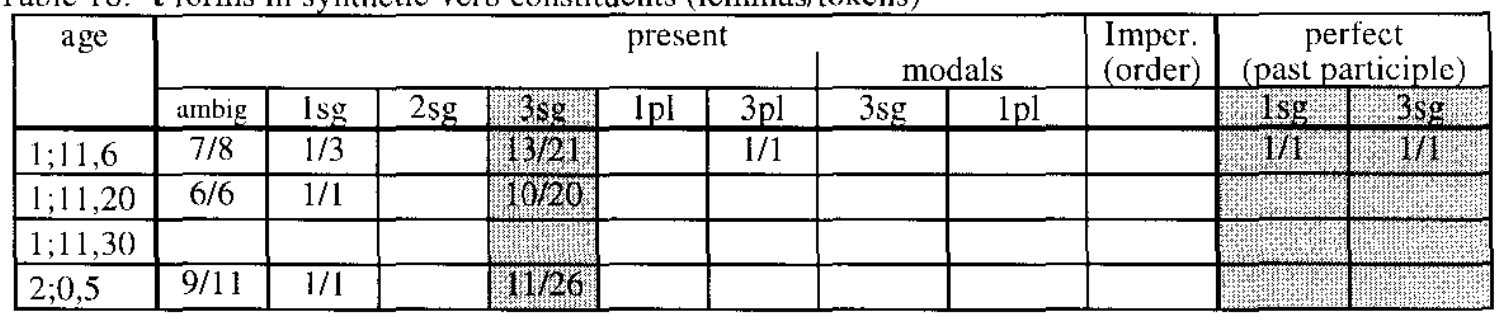

Table 17: $\varnothing$ forms in synthetic verb constituents (lcmmas/tokens)

\begin{tabular}{|c|c|c|c|c|c|c|c|c|c|c|c|c|c|c|}
\hline \multirow[t]{2}{*}{ age } & \multicolumn{6}{|c|}{ present } & \multicolumn{3}{|c|}{ modals } & $\begin{array}{l}\text { Imp. } \\
\text { (order) }\end{array}$ & \multicolumn{4}{|c|}{$\begin{array}{c}\text { perfect } \\
\text { (past participle) }\end{array}$} \\
\hline & anbig & (S) & $2 \mathrm{sg}$ & $3 \mathrm{sg}$ & $1 \mathrm{pl}$ & $3 \mathrm{pl}$ & uncl & W & $1 \mathrm{pl}$ & 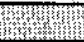 & uncl & $1 \mathrm{sg}$ & $3 \mathrm{sg}$ & $3 \mathrm{pl}$ \\
\hline $1 ; 11,6$ & $1 / 1$ & $1 / 5$ & & $2 / 2$ & & & & & & Wha & & $1 / 1$ & $2 / 3$ & \\
\hline $1 ; 11,20$ & $9 / 12$ & $1 / 1$ & $1 / 1$ & & & & $1 / 1$ & U/W & & $2 / 3$ & $1 / 2$ & & & $1 / 1$ \\
\hline $1 ; 11,30$ & & $4 /$ / & $1 / 1$ & $1 / 1$ & & & & Wha & & 272 & & & & \\
\hline $2 ; 0,5$ & $3 / 3$ & $5 / 8$ & & $1 / 1$ & & & & & & W & $1 / 2$ & & $1 / 1$ & \\
\hline
\end{tabular}

Table 18: -e forms in synthetic verb constituents (lemmas/tokens)

\begin{tabular}{|c|c|c|c|c|c|c|c|c|c|c|c|c|}
\hline \multirow[t]{2}{*}{ age } & \multicolumn{6}{|c|}{ present } & \multicolumn{3}{|c|}{ modals } & $\begin{array}{l}\text { Imp. } \\
\text { (order) }\end{array}$ & \multicolumn{2}{|c|}{$\begin{array}{c}\text { perfect } \\
\text { (past participle) }\end{array}$} \\
\hline & ambig & (Is) & $2 \mathrm{sg}$ & $3 \mathrm{sg}$ & Ipl & $3 \mathrm{pl}$ & lsg & $3 \mathrm{sg}$ & $1 \mathrm{pl}$ & 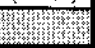 & $1 \mathrm{sg}$ & $3 \mathrm{sg}$ \\
\hline $1 ; 11,6$ & $1 / 1$ & WWWW & & & & & & & & 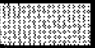 & & \\
\hline $1 ; 11,20$ & $2 / 2$ & 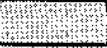 & & $1 / 1$ & & & & & & 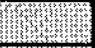 & & \\
\hline $1 ; 11,30$ & & 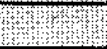 & & & & & 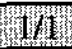 & & & 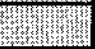 & & \\
\hline $2 ; 0,5$ & & & & & & & & & & & & \\
\hline
\end{tabular}

Table 19: -st forms in synthetic verb constituents (lcmmas/tokens)

\begin{tabular}{|c|c|c|c|c|c|c|c|c|c|c|c|c|}
\hline \multirow[t]{2}{*}{ age } & \multicolumn{6}{|c|}{ present } & \multicolumn{3}{|c|}{ modals } & $\begin{array}{l}\text { Imp. } \\
\text { (order) }\end{array}$ & \multicolumn{2}{|c|}{$\begin{array}{c}\text { perfect } \\
\text { (past participle) }\end{array}$} \\
\hline & ambig & $1 \mathrm{sg}$ & $2 \mathrm{Sg}$ & $3 \mathrm{sg}$ & $1 \mathrm{pl}$ & $3 \mathrm{pl}$ & $1 \mathrm{sg}$ & $3 \mathrm{sg}$ & $1 \mathrm{pl}$ & & 1 sg & $3 \mathrm{sg}$ \\
\hline $2 ; 0,5$ & & & n'W & & & & & & & & & \\
\hline
\end{tabular}

The rate of target subject-verb-agreement clearly increases in comparison to premorphology but it does not exceed the 50\% mark. Important with respect to the emergence of verbal categories is the acquisition of the first past tense forms. Without any exception these are suppletive past tense forms of the verb sein 'to be' - war/waren 'was/were'. In the whole period we find 5 instances of these forms, $\mathrm{cf}$.

$\begin{array}{llll}\text { (11) } 1 ; 11,20 & \text { (zu) grob waren } & 3 \mathrm{pl} & \text { 'were (to) big' } \\ 1 ; 11,30 & \text { (wer) war (e)s? } & 3 \mathrm{sg} & \text { '(who) was it? } \\ 2 ; 0,5 & \text { da war jemand } & 3 \mathrm{sg} & \text { 'someone was there ' } \\ & \text { war das } \mathrm{xx} & 3 \mathrm{sg} & \text { 'was it } \mathrm{xx}^{\prime} \\ & \text { Oma ursel war das } & 3 \mathrm{sg} & \text { 'this was grandmother u.' }\end{array}$

Additionaly, the suppletive 1./3.pl.pres.ind. form of sein 'to be' - sind 'are' occurs, cf.

$\begin{array}{llll}\text { (12) } 1 ; 11,30 & \text { freunden da sind } & 3 \mathrm{pl} & \text { 'friends are here' } \\ & \text { da sind die (räder) } & 3 \mathrm{pl} & \text { 'there are they (whecls)' } \\ & \text { beide hochklettert sind wir } & 1 \mathrm{pl} & \text { 'we both are climbed up' }\end{array}$

An important step in the acquisition of the verb is the occurence of periphrastic verb constructions. In the four recordings of the protomorphological phase 12 constructions are 
documented. These are a) present tense constructions with a modal verb as auxiliary plus an infinitive form, cf.

$\begin{array}{lllll}1 ; 11,6 & \text { soll } & \text { schlafen } & 3 \mathrm{sg} & \text { 'should sleep' } \\ & \text { kann } & \text { malen } & 3 \mathrm{sg} & \text { 'can draw' } \\ & \text { setzen } & \text { kann } & 3 \mathrm{sg} & \text { 'can sit down' } \\ & \text { hochsetzen } & \text { kann } & 3 \mathrm{sg} & \text { 'can sit on sth high' } \\ & \text { einkacken } & \text { darf } & 3 \mathrm{sg} & \text { 'can fill one's pants' } \\ & \text { müssen } & \text { ausziehen } & 1 \mathrm{pl} & \text { 'have to take off' } \\ 1 ; 11,20 & \text { gehen } & \text { muß } & ? & \text { 'have to go' } \\ 1 ; 11,30 & \text { malen } & \text { kann } & 3 \mathrm{sg} & \text { 'can draw' } \\ 2 ; 0,5 & \text { angucken } & \text { wollen } & 1 \mathrm{pl} & \text { 'want to look at' }\end{array}$

and b) perfect tense constructions with a person/number form of sein 'to be' or of haben 'to have' as auxiliary plus a past participle, cf.

$\begin{array}{lllll}1 ; 11,6 & \text { hab } & \text { hinnengeben } & ? & \text { 'have given away' } \\ 1 ; 11,20 & \text { puttgang } & \text { is }(\mathrm{t}) & 3 \mathrm{sg} & \text { 'is broken down' } \\ 1 ; 11,30 & \text { hochklettert } & \text { sind } & 1 \mathrm{pl} & \text { 'are climbed up' }\end{array}$

The order of the constituents of these constructions is target like in some of the first constructions at $1 ; 11,6$. From $1 ; 11,20$ on we find the reverse nontarget order without any exception. The difference is not due to syntactical aspects as there could be question structure or subordinated clause structure. Thus it is interesting to note that in these reversed constructions the finite verb is in the last or sometimes next to the last position whereas the infinite verb is in the first or second position of the utterance.

\section{Emergence of inflectional categories}

If we look at the categories the child's forms belong to the most common way is to start from the target system and to count the instances of forms resembling the respective categories. This method has been used here as well. However, as has been discussed at various places (Slobin 1985, Clahsen 1996, Tomasello 1992) we can't be sure that the child has the same form-meaning correlations in his grammar from the very beginning. Only broad crosslinguistic and very detailed research can give an answer if and how far child grammar is different form adult grammar with respect to the category system. As we know by the research of Slobin and colleagues and others as well, it is very likely that there are some semantic or pragmatic domains of child and human life that crosslinguistically tend to be lexicalized and maybe also grammaticalized early, $\mathrm{cf}$. the examples for 'grammaticizable notions' in Slobin (1985:1172ff). To assign basic oppositions like these the child can only use language material available from the input. A mismatch of child and adult categories is programed.

Having in mind this problem the following tables could be read as the order of emergence of appropriate forms in the adult categories. 
Table 20: target form-category-correlation with synthetic verb forms (tokens - \% in relat. to utter. with verbs)

\begin{tabular}{|c|c|c|c|c|c|c|c|c|c|}
\hline age & $\begin{array}{l}\text { unclear } \\
\text { agreem. }\end{array}$ & $\begin{array}{c}3 . s g . \\
\text { pres ind. }\end{array}$ & $\begin{array}{c}\text { l.sg. } \\
\text { pres ind. }\end{array}$ & $\begin{array}{l}\text { (past part.) } \\
\text { perfect* }\end{array}$ & $\begin{array}{c}\text { 3.pl. } \\
\text { pres ind. }\end{array}$ & $\begin{array}{l}\text { 2.sg. } \\
\text { imp. }\end{array}$ & $\begin{array}{c}\text { 1.pl. } \\
\text { pres. ind. }\end{array}$ & pret. & $\begin{array}{l}\text { 2.sg. } \\
\text { pres. ind. }\end{array}$ \\
\hline $1,8.9$ & $28-62,2 \%$ & 10 & 2 & 1 & 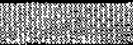 & (rirgzen) & (1) & 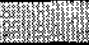 & \\
\hline $1 ; 8,29$ & $25-54,3 \%$ & 8 & & 2 & 1 & 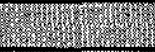 & 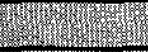 & & \\
\hline $1 ; 9,14$ & $26-49,1 \%$ & 14 & 2 & 1 & 1 & $\begin{array}{l}\text { (4 frozen: } \\
\text { iroming) }\end{array}$ & & & \\
\hline $1 ; 10.0$ & $\mathbf{3 3}-49,3 \%$ & 9 & 5 & 2 & 3 & $\begin{array}{c}1 \\
(+3 \text { frozen })\end{array}$ & & & \\
\hline $1 ; 11,6$ & $55-39,9 \%$ & 16 & 4 & 7 & 1 & $\begin{array}{c}\text { (4 frozen, } \\
1 \text { imit.) }\end{array}$ & 2 & & \\
\hline $1 ; 11,20$ & $61-55,0 \%$ & 21 & 1 & 3 & 1 & $\begin{array}{c}3 \\
(+2 \text { frozen }) \\
\end{array}$ & & $\begin{array}{c}1 \\
\text { 3.pl. }\end{array}$ & \\
\hline $1: 11,30$ & $29-32,6 \%$ & 26 & 2 & 1 & 5 & & 3 & $\begin{array}{c}1 \\
3 . \mathrm{sg} .\end{array}$ & 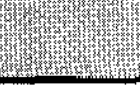 \\
\hline $2 ; 0,5$ & $44-40,4 \%$ & 26 & 8 & 3 & 3 & (8 frozen) & 4 & $\begin{array}{r}\mathbf{3} \\
3 . \mathrm{sg} \\
\end{array}$ & 1 \\
\hline $2 ; 0,29$ & $74-30,2 \%$ & 56 & 19 & 4 & 3 & $\begin{array}{c}3 \\
(+4 \text { frozen }) \\
\end{array}$ & 2 & $\begin{array}{r}3 \\
3 . \mathrm{sg} \\
\end{array}$ & 7 \\
\hline $2 ; 1,13$ & $56-26,8 \%$ & 40 & 40 & 1 & 1 & $\begin{array}{c}\mathbf{3} \\
\text { (9 frozen) } \\
\end{array}$ & 5 & $\begin{array}{c}1 \\
\text { 3.sg. }\end{array}$ & 6 \\
\hline
\end{tabular}

* again I counted all forms showing a stem vowel change and/or the prefix (ge-/c-); forms with only one of these features are not completely target like; additionally, single past participle forms lack the (target) finite verb

Table 21: target form-category-correlation with periphrastic verb forms (tokens)

\begin{tabular}{|c|c|c|c|c|c|c|c|c|c|}
\hline agc & $\begin{array}{l}\text { unlear } \\
\text { agreem. }\end{array}$ & $\begin{array}{l}3 . s g . \\
\text { pres ind }\end{array}$ & $\begin{array}{l}\text { 3.sg. } \\
\text { perfect }\end{array}$ & $\begin{array}{c}\text { 1.pl. } \\
\text { pres. ind. }\end{array}$ & $\begin{array}{c}\text { 1.sg. } \\
\text { perfect }\end{array}$ & $\begin{array}{c}\text { 1.sg. } \\
\text { pres ind. }\end{array}$ & $\begin{array}{l}3 . \mathrm{sg} . \\
\text { pret. }\end{array}$ & $\begin{array}{c}\text { 3.pl. } \\
\text { pres. ind. }\end{array}$ & $\begin{array}{c}\text { 1.pl. } \\
\text { perfect }\end{array}$ \\
\hline $1,8.9$ & $n^{2}$ & 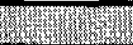 & 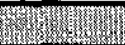 & 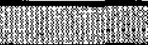 & 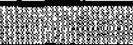 & prophas & (19. & MIX" & 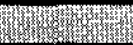 \\
\hline $1 ; 8,29$ & $\sqrt{203}$ & (2) & 1 & $\sqrt{17}$ & $\sqrt{25}$ & 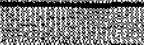 & (4) & 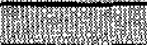 & $\sqrt{7+2}$ \\
\hline $1 ; 9,14$ & 98 & 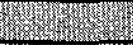 & 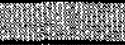 & 4 & 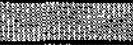 & 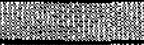 & 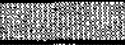 & 8 & 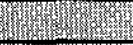 \\
\hline $1 ; 10,0$ & 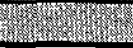 & 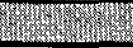 & 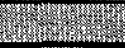 & 27 & 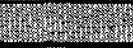 & 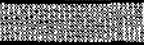 & 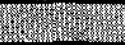 & Thy & Pxy \\
\hline $1 ; 11,6$ & $\begin{array}{l}1 \text { pres. } \\
1 \text { perf. }\end{array}$ & 4 & W & 1 & & & & & \\
\hline $1 ; 11,20$ & 1 pres. & & 2 & & 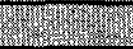 & 2 & 7 & 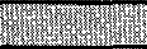 & (2) \\
\hline $1 ; 11,30$ & & 1 & 1 & (1) & 1 & (1- & 1) & 9. & 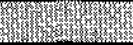 \\
\hline $2 ; 0,5$ & & & & 1 & (3) & ${ }^{2}$ & (2) & 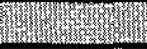 & 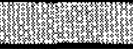 \\
\hline $2 ; 0,29$ & $\begin{array}{l}3 \text { pres. } \\
1 \text { perf. } \\
1 \text { prel. }\end{array}$ & 8 & 1 & 1 & 3 & 6 & 2 & 1 & 1 \\
\hline $2 ; 1,13$ & 1 pres. & 2 & 1 & 1 & 4 & 5 & 7 & 1 & I \\
\hline
\end{tabular}

Table 22 summarizes the order of emergence of inflectional categories of the verb:

Table 22: order of the (recurrent) emergence of categories (i.c. target form-category-correlations)

\begin{tabular}{|l|l|}
\hline \multicolumn{1}{|c|}{ agc } & emergence of categories \\
\hline $1,8.9$ & 3.sg.pres.ind. \\
\hline $1 ; 8,29$ & $/$ \\
\hline $1 ; 9,14$ & 1 \\
\hline $1 ; 10,0$ & 1.sg.pres.ind. \\
\hline $1 ; 11,6$ & 3.sg.pres.ind. (periphr./modal) ^ perfect (= past part.) \\
\hline $1 ; 11,20$ & 3.sg.perf.ind. (periphr.) \\
\hline $1 ; 11,30$ & 3.pl.pres.ind. \\
\hline $2 ; 0,5$ & 1.pl.pres.ind. \\
\hline $2 ; 0,29$ & $\begin{array}{l}\text { 2.sg.pres.ind. ^ } 3 . s g . p r e t . \wedge \\
\text { 1.sg.pres.ind. (periphr./modal)^ } 1 \text { 1.pl.pres.ind. (periphr./modal) }\end{array}$ \\
\hline $2 ; 1,13$ & 2.sg.imp. \\
\hline
\end{tabular}




\section{Emergence of mini-paradigms}

\subsection{Data analyses}

To discover the onset of the development of paradigms in language acquisition KilaniSchoch/Dressler (2000) ${ }^{17}$ propose five criteria to qualify an inflectional form as a potential member of a paradigm: not imitative, not formulaic, articulatory accuracy, use in contrasting contexts, recurrence. I would propose to add the criterion of stable correlation with a potential grammatical meaning to exclude cases of arbitrary or accidental use of forms from paradigm construction. Only forms which could be characterized as the default (or as the base) form are tolerated to occur in different category contexts. As also Klampfer (this volume) discusses, the criterion of recurrence of an inflectional form is a very strong criterion given a data base consisting of one recording a week or within two weeks. For German I propose to weaken this criterion to recurrence of the form-meaning-correlation with a verb of the same stem or base. Forms regarded as the onset of a paradigm should occur within a time span of four or five weeks.

This way in premorphology only the $-e n$ vs. $-t$ contrasts of machen 'to do' (8), aufmachen 'to open', and malen 'to draw' $(8,10)$ can be regarded as candidates or precursors of miniparadigms.

Table 23: candidates of mini-paradigms in premorphology

\begin{tabular}{|c|c|c|}
\hline age & 2 members & 3 members \\
\hline $1 ; 9,14$ & 2 & \\
\hline $1 ; 10,0$ & 3 & \\
\hline
\end{tabular}

In the period of Anna's first 70 verb lemmas no example for a "true" mini-paradigm is documented. Only after the raise of the verb lexicon beyond the 100 lemma mark (cf. (5)) the first three member paradigm was documented. This confirms with the findings in Klampfer (this volume) for the Austrian girl Katharina.

In protomorphology we find an increasing number of candidates of mini-paradigms and the first "true" mini-paradigms.

Table 24: candidates and mini-paradigms in protomorphology

\begin{tabular}{|c|c|c|}
\hline age & 2 members & 3 members \\
\hline $1 ; 11,6$ & 4 & 1 \\
\hline $1 ; 11,20$ & 6 & \\
\hline $1 ; 11,30$ & 3 & \\
\hline $2 ; 0,5$ & 4 & 3 \\
\hline
\end{tabular}

16 lemmas are involved in these potential paradigmatic contrasts in protomorphology. Almost all of them contain an $-e n$ vs. $-t$ contrast. In the 3 member cases either a past participle or a $-\varnothing$ form (1.sg.pres.ind.) is added. One contrast is of suppletive nature, the forms of sein 'to be' (ist, sind, war) create one of the 3 member contrasts in $2 ; 0,5$.

In chapter 4.3.1. I outlined the new developments in the acquisition of verb morphology observable in $2 ; 0,29$ and $2 ; 1,13$ and I proposed that the transition to a new stage in verb grammar has started. With respect to inflectional contrasts this involves the emergence of target infinitive forms in periphrastic constructions and a first remarkable amount of $-s t$ forms in 2.sg. Also, contexts of 1./3.pl. occur more regularly. Like in most German corpora contexts for 2.pl. don't occur at all. The development of paradigmatic contrasts in the two recordings is as follows:

17 Cf. also Kilani-Schoch (this volume). 
Table 25: candidates and mini-paradigms in transition to modularized morphology

\begin{tabular}{|c|c|c|c|}
\hline age & $\mathbf{2}$ members & 3 members & 4 members \\
\hline $2 ; 0,29$ & 8 & 3 & 1 \\
\hline $2 ; 1,13$ & 5 & 6 & 1 \\
\hline
\end{tabular}

In only two recordings now 17 lemmas are involved in potential paradigmatic contrasts. 3 member contrasts occur more or less regularly and the first 4 member contrast is documented. The first four member paradigm is build up by the (main!) verb haben 'to have/get', the second by malen 'to draw' which also was one of the first verbs with form contrasts.

\subsection{Steps towards mini-paradigms}

The (morphological) steps towards mini-paradigms we have observed in the data of Anna can be summarized as follows:

premorphological steps:

- different rote learned morphological forms in isolated use:

- unspecified (default) form of the verb in -en

- (contextual) specified forms, predominantly the $-t$ form but also $-\varnothing$ and past participle forms

- the specified forms are mapped to specific situative contexts

- very few and single morphological contrasts with one lemma

- no systematic correlation between the morphological forms can be assumed protomorphological steps:

- increase of the active verb lexicon beyond 100 lemmas

- increase of subject-verb-agreement correlated with increasing use of subjects ${ }^{18}$ and more complex utterance structures in general

- increase of verbs with the (basic) morphological contrast of $-e n$ vs. $-t$

- occurence of 1./3.pl. and 2.sg. contexts

- emergence of rote learned modal verbs

- emergence of rote learned periphrastic forms

- first recurring 3 member contrasts: unspecified -en vs. -t (3.sg. or perfective meaning) plus $-\varnothing$ (1.sg.) or past participle form

steps in transition to modularized morphology:

- utterances containing subject, object and the finite verb become regular

- mastering of periphrastic perfect and periphrastic modal constructions

- emergence of past forms, differentiation of the tempus domain: present (with imperfect/perfect) vs. past

- emergence of -st forms for 2.sg.

- increase of 3 member contrasts: mainly unspecified -en vs. -t (3.sg. or perfective meaning) plus - $\varnothing$ form (1.sg.)

- first recurring 4 member contrast (-en, -t, - $\varnothing$ plus -st)

What could be concluded from this summary is

a) that the emergence of mini-paradigms can be seen as the logical result of the acquisition of (rote learned) linguistic material to communicate about different kinds of situations.

b) that mini-paradigms in Anna's grammar and perhaps in German children in general are of different nature then paradigms adults employ.

The statement in a) should provoke the question to which extent we can assume that morphological contrasts in protomorphology are meaningful. If we assume that all forms are still rote learned and stored as seperate linguistic units the emergence of mini-paradigms

18 Since 1;11,6 subject elements occur in more than 15\% of Anna's utterances, cf. D. Bittner. (2000). 
happened by chance. In this case mini-paradigms would be a by-product of the acquisition of seperate forms of one lemma - and exclusively a theoretical/descriptional term. I will discuss this in chapter 7.

The conclusion in b) arises from the fact that an unspecified -en form is part of the morphological constrasts up to the end of the observed period. This form is not part of an adult paradigm, here $-e n$ is restricted to 1./3.pl.pres.ind. and to infinitives in periphrastic present constructions. Additionally, Anna is using the $-t$ form different to adult language. Beside the target occurence in 3.sg.pres.ind. this form is also used in perfective contexts. The common assumption is that the $-t$ form replaces the articulatory more complex past participle by phonogical reasons. It seems to me that there are some problems with this assumption. Typically Anna replaces target forms by using the -en form. Having this in mind it is much more surprising that Anna uses - $t$ forms in perfective contexts also when the target form of the past participle ends in $-e n$, cf.

$\begin{array}{llll}\text { (15) (ich) auch ein geld gebt } & \leftarrow \text { gegeben } & \text { 'I also have given money' } & (1 ; 9,14) \\ \text { opa (=3.sg) gebt } & \leftarrow \text { gegeben } & \text { 'grandfather has given' } & (1 ; 11,6) \\ \text { wegschmeißt } & \leftarrow \text { weggeschmissen } & \text { 'has thrown away' } & (1 ; 11,6) \\ \text { auffreßt } & \leftarrow \text { aufgefressen } & \text { 'has eaten up' } & (2 ; 0,5) \\ \text { aufbeißt } & \leftarrow \text { aufgebissen } & \text { 'has bite open' } & (2 ; 0,5) \\ \text { runterfallt } & \leftarrow \text { runtergefallen } & \text { 'was falling down' } & (2 ; 0,29) \\ \text { ausgeht } & \leftarrow \text { ausgegangen } & \text { 'was getting out' } & (2 ; 0,29)\end{array}$

For these cases often overgeneralization of the $-t$ past participle pattern has been assumed. But the child still hasn't acquired the target pattern. Only 6 target like past participle forms (i.e. prefix+stem+suffix) are documented. Shall we assume homonymic use of $-t$ forms for 3.sg.pres.ind. and for perfectivity or is the child analyzing a unified meaning with $-t$ ? Clahsen (1988) proposed $-t$ symbolizes intransitivity in early German. This proposal has been disproved (cf. a.o. Weissenborn 1990). However, the question if $-t$ forms in this early period are of different nature than in adult language is not finally answered with the disproval of intransitivity.

We are coming back here to the question under a): Are the morphological contrasts meaningful in protomorphology? In accordance to Tomasellos approach (Tomasello 1992, 2000) this question can be reformulated as: Has the child already started to analyze word structure? Occurence of nontarget morphological forms like the above mentioned (probable) past participles can provide evidence for meaningful contrasts in protomorphology.

\subsection{Analogical substitutions}

The main type of non-target use of a morphological form is the already discussed use of -en forms. It can be assumed that the child picks up this form as the prototypical verb form from the input by frequency reasons. In adult language the $-e n$ form has high frequency because of its syncretistic occurence in 1./3.pl.pres., 1./3.pret. (wir/sie sagen 'we/they say' wir/sie sagten 'we/they said') and as infinitive in the very frequent periphrastic constructions with modal verbs (kann/kannst/könnt/können sagen 'can say') as well as in subordinate verb constructions (er beginnt zu rennen 'he starts to run'). The unspecified character of this form in Anna's grammar especially becomes clear in the use of $-e n$ forms for requests, i.e. in imperative function. The preferential use of -en forms can be interpreted as that Anna has acquired the difference between the concept/category of the verb and (the) concepts/categories assigned by other word classes. An -en form assigns that the scenario the child would like the hearer to spend attention on is one of the kind the target language specifies with verbs.

The next type of non-target use of verb forms is the occurence of $-t$ forms in other than 3.sg.pres.ind. contexts (but not 2.pl.pres.ind.). It has already been discussed in 6.2. that this 
probably is related to a perfective meaning of $-t$ forms. Also I have discussed that relating this occurencies to phonological reduction of target past participles is doubtful. The hypothesis is the child starts to associate the $-t$ form with a general meaning unifying its occurence in 3.sg.pres.ind. and in perfective contexts. Further research has to show if this can be proved. It should only be mentioned here that if one accepts the assumption of an unspecified or default verb form in -en in early child grammar it is also likely that the child tries to find out which meaning is correlated with other forms of verbs early.

There are only rare examples of further non-target use of verb forms. The main type is of not changing the stem vowel of strong verbs as it is appropriate in adult language. First examples have been the past participle forms given in 6.2. Of the same type are the 3.sg.pres.ind. forms:

$\begin{array}{clll}\text { (16) wascht } & \leftarrow \text { wäscht } & \text { 'wash' } & (1 ; 9,14 / 1 ; 11,6) \\ \text { gebt } & \leftarrow \text { gibt } & \text { 'give' } & (1 ; 11,6) \\ \text { eßst } & \leftarrow \text { ißjt } & \text { 'eat' } & (1 ; 11,20) \\ \text { mitfahrt } & \leftarrow \text { mitfährt } & \text { 'drive with' } & (1,11: 20) \\ \text { auffreßst } & \leftarrow \text { auffrißt } & \text { 'eat up' } & (2 ; 0,5) \\ \text { runterfallt } & \leftarrow \text { runterfällt } & \text { 'fall dawn' } & (2 ; 0,29)\end{array}$

These strong verbs require a stem alternation in 2./3.prs. Also if the infinitive is not documented in the data one can assume that the child has the infinitive form of these verbs as underlying form in her/his lexicon and the non-target use is based on the universal semiotic principle of the uniformity of signs (Dressler et al. 1987). According to this principle it is more natural, i.e. presupposed that a sign stays identical in its different usages. This is confirmed by the overwelming amount of German verbs, i.e. the weak verbs which constitute the only productive class. Thus the respective non-target treatment of strong verbs is motivated by universal as well as by system specific principles.

Naturally, there are different possibilities to interprete the occurence of these substitutions. One of them is to regard them (especially the first ones) as the result of the omission of further target language material like modals in the case of -en forms or auxiliaries in the case of $-t$ forms and to relate it to frequency and pragmatic reasons that it be just $-e n$ and $-t$ forms occuring in the reduced verb phrases. But, in parallel to the common assumption that the child has categorized verbs vs. nouns early (i.e. before it starts to use different forms of verbs) and in parallel to the assumption of something like an optional infinitve stage in early verb acquisition (i.e. the mapping or classifying of one of the input types as 'beeing verb') the assumption that the child is able to mapp or to classify other forms of verbs to special contexts is likely and has to be proved. If one excludes this possibility one has to explain why the child can categorize the one and not the other. If one supports this way of explanation one has to show by which kind of learning processes the child is able to develop from rote learning to analysation and classification of form-meaning correlations.

\section{Thoughts on the role of protomorphology in paradigm building}

The discussion on pre- and protomorphology has shown that in the beginning we can't assume that the child has a grammatical understanding of inflectional forms. Rote learned verb forms are mapped to situative contexts with a relatively fixed structure, fixed for instance in time, event, and object structure. I assume that the child only step by step ${ }^{19}$ could extract inherent features of the situative structure and correlate them with features of the mapped language

19 Examples for a step by step differentiation of grammatical domains in language acquisition are discussed in D. Bittner (1998, 1999). 
elements. There are some evidence that protomorphology is the phase in which the child finds out basic oppositions of morphological systems.

When does the child start to look beyond the single rote learned form? At the end of protomorphology (at $2 ; 0,5$ ) the most common contrast of $-e n$ vs. $-t$ forms is documented as a recurrent contrast for $23,5 \%$ of the verb lemmas, i.e. for nearly every $4^{\text {th }}$ lemma. This is clearly not enough to assume a productive morphological relation between both forms, especially having in mind the still high amount of (non-target) $-e n$ forms. Otherwise, 162 verb lemmas are documented up to 2;0,5. These are only the lemmas documented in the time of recording. Anna's active verb lexicon would clearly consist of a considerable greater number of lemmas. Additionally recurrent inflectional types have increased to 7 (cf. table 22). All in all to much to assume that all contrasting forms could still be rote learned. The question arising is what kind of verb usage lies between the sheer rote learned phase and the phase of productive morphology? Most linguists dealing with the development from rote learning to productive morphology ${ }^{20}$ assume a phase of analogical learning. But it remains more or less open what kind of analogies we have to assume, especially in which respect these analogies differ from productive morphological processing.

I propose that we have to assume a phase characterized by accumulative learning. After sheer rote learning the child accumulates forms of the type it was becoming familiar with by rote learning. In other words the mapping of forms to special situative contexts becomes easier the more instances of the same type of mapping are stored already. For instance, the more lexemes the child has learned which end in -en and have a verb meaning the better s/he has access to new lexems with the same combination of features. And the more the child becomes familiar with form contrasts like the $-e n$ vs. $-t$ (vs. $-\varnothing \ldots$...) contrast the more s/he "expects" the same contrast with new lemmas of the same type and can extract the appropriate forms more easily from the input. ${ }^{21}$ What probably the child is doing before s/he starts to analyse formmeaning-correlations is accumulative learning and pattern learning. This way $\mathrm{s} / \mathrm{he}$ stores the necessary amount of instances of the same type ("critical mass") to change to generalization and abstraction on grammatical features of the forms and structures acquired. This order of phases is probably repeated with every new grammatical structur. Thus, after an initial phase of sheer rote learning of the very first structures we will find a coexistence of rote learned structures, accumulated structures, analogical and finally productive structures as long as the child is learning her/his language. After the first or basic dissociations of modules the processes leading to further dissociations within modules and submodules will repeat the processes of the first dissociation and will do that in different domains at the same time. Accordingly, paradigm construction is a process of repeated dissociation as long as the child has acquired the full set of paradigmatic relations.

The parallel existence of the different learning mechanisms comes to light in the processes after $2 ; 0,5$. We have found not as much a quantitative spurt but a qualitative spurt. Within three weeks the number of recurrent inflectional types is increased from 7 to 12 (cf. tables 2022 ). At $2 ; 1,13$ recurrent $-e n$ vs. $-t$ contrasts are documented for nearly $28 \%$ of the lemmas. $12 \%$ of the lemmas with this contrast show additionally the stem form $(-\varnothing)$ for 1. sg.pres.ind. Whereas the new inflectional types occure by rote learning and are documented by only a few instances the pattern of $-e n--t-\varnothing \varnothing$ increases by accumulative learning due to expectation of these contrasts and starts to become productive patterns of category symbolization.

20 Cf. a.o. MacWhinney (1978), Plunkett (1993), Dressler/Karpf (1995), Gentner/Markman (1997), Tomasello (2000).

21 Some models of neural nets (for instance ART nets, cf. Carpenter/Grossberg 1988) contain a seperate level of nodes, which models the expectations of the learner in dealing with new input together with the value 'vigilance'. For an application on the acquisition of semantic relations in the lexicon, cf. Friedrich (2000). 


\section{References}

Bennis, H. et al (1995): Bennis, H. / M. den Dikken / P. Jordens / S. Powers / J. Weissenborn, Picking up particles. In: Proceedings of the Boston Conference on Language Development 1994, 70-81.

Bittner, A. (1995): Starke "schwache" und schwache "starke" Verben. Tübingen: Narr.

Bittner, D. (1998): Entfaltung grammatischer Relationen im NP-Erwerb: Referenz. In: Folia Linguistica XXXI/3-4 (C). 255-283.

(1999): Erwerb des Konzepts der Quantifikation nominaler Referenten im Deutschen. In: Meibauer, J. / M. Rothweiler (Hrsg.): Das Lexikon im Spracherwerb. Tübingen: Franke. 51-74. (2000): Are there correlations in the acquisition of definite pronouns and finite verbs in German? In: ZAS Papers in Linguistics 15, 199-217.

Carpenter, G. A. / Grossberg, St. (1988): Neural dynamics of category learning and recognition: attention, memory consolidation, and amnesia. In: Davis, J.L. / R.W. Newburgh / E.J. Wegman (eds.): Brain, structure, learning, and memory. AAAS Selected Symposia Series.

Clahsen, H. (1988): Normale und gestörte Kindersprache. Amsterdam/Philadelphia: Benjamins.

/ M. Penke / T. Parodi (1993): Functional Categories in Child German. In: Language Acquisition 3, 395-429.

- / S. Eisenbeiß/M. Penke (1996): Lexical learning in early syntactic development. In: Clahsen, H.: Generative Perspectives on Language Acquisition. Amsterdam/Philadelphia: Benjamins 129-159.

Dressler, W. U. / W. Mayerthaler / O. Panagl / W. U. Wurzel. (1987): Leitmotifs in Natural Morphology. Amsterdam: Benjamins.

- / A. Karpf (1995): The theoretical relevance of pre- and protomorphology in language acquisition. Yearbook of Morphology 1994, 99-122.

Friedrich, M. (2000): Der sprachliche Einfluß auf das Auftreten von Exklusionen bei Kindern. In: ZAS Papers in Linguistics 15, 218-231.

Kilani-Schoch, M. (this volume): Early verb development in two French-speaking children.

- / W. U. Dressler. 2000. The emergence of verb paradigms in two French corpora as an illustration of general problems of pre- and protomorphology. Poster presented at the $9^{\text {th }}$ Int. Morphology Meeting, February 2000.

Klampfer, S. (this volume): Early verb development in one Austrian child.

MacWhinney, B. (1978): The acquisition of morphophonology. Chicago: Univ. of Chicago Press. (2000): The CHILDES project: tools for analyzing talk. Vol. I: Transcription, format and programs. Mahwah, NJ: Lawrence Erlbaum Associates.

Plunkett, K. (1993): From rote learning to system building. In: Cognition 48, 21-69.

Slobin, D. I. (Hrsg.) (1985): The cross linguistic study of language acquisition. vol. I: The Data; vol. II: Theoretical Issues. Hillsdale

Tomasello, M. (1992): First verbs. A case study of early grammatical development. Cambridge: Cambridge University Press.

- (2000): Acquiring syntax is not what you think. In: Bishop, D./ L. B. Leonard (eds.): Speech and language impairments in children : cause, characteristics, intervention and outcome. Hove: Psychology Press, 1-15.

Vollman, R. / M. Sedlak / B. Müller / M. Vassilakou (1997): Early verb inflection and noun plural formation in four Austrian children: The demarcation of phases an interindividual variation. In: Dziubalska-Kolaczyk, K. (ed.), Papers a. Studies in Contrastive Linguistics 33, Poznan, 59-78.

Wexler, K. (1994): Optional infinitives, head movement, and the economy of derivations. In: Lightfoot, D. / N. Hornstein (eds.): Verb Movement. London: Cambridge Univ. Press. 305-350.

Weissenborn, J. (1990): Functional categories and verb movement: The acquisition of German syntax reconsidered. In: Rothweiler, M. (Hrg.): Spracherwerb und Grammatik. (Linguistische Berichte, Sonderheft 3/1990), 190-224.

(1994): Constraining the childs grammar: Local well-formedness in the development of verb movement in German and French. In: Lust, B./M. Suñer/J. Whitman (eds.): Syntactic theory and firat language acquisition: Cross-linguistic perspectives. Hillsdale/ New Jersey: Erlbaum. 215-247. 